Terr. Atmos. Ocean. Sci., Vol. 17, No. 4, 883-902, December 2006

\title{
Methane Migration and Its Influence on Sulfate Reduction in the Good Weather Ridge Region, South China Sea Continental Margin Sediments
}

\author{
Saulwood Lin ${ }^{1,}$ *, Wei-Chi Hsieh ${ }^{1}$, Yee Cheng Lim ${ }^{1}$, \\ Tsanyao Frank Yang ${ }^{2}$, Char-Shine Liu $^{1}$, and Yunshun Wang ${ }^{3}$
}

(Manuscript received 10 September 2006, in final form 6 November 2006)

\begin{abstract}
Bacteria sulfate reduction is a major pathway for organic carbon oxidation in marine sediments. Upward diffusion of methane from gas hydrate deep in the sedimentary strata might be another important source of carbon for sulfate reducing bacteria and subsequently induce higher rates of sulfate reduction in sediments. Since abundant gas may migrate upward to the surface as a result of tectonic activity occurring in the accretionary wedge, this study investigates the effect of methane migration on the sulfate reduction process in continental margin sediments offshore southwestern Taiwan. Piston and gravity core samples were taken in order to evaluate vertical and spatial variations of sulfate and methane. Pore water sulfate, sulfide, methane, sediment pyrite, and organic carbon were extracted and analyzed.

Rapid sulfate reduction, high pyrite contents in sediments and higher concentrations of dissolved sulfide and methane were found in the study area with relatively low organic carbon concentrations. Up to $300 \mu$ mole g $^{-1}$ of pyrite, $10 \mathrm{mM}$ dissolved sulfide and $9 \mathrm{mM}$ methane were found in the study region. Sulfate depletion was as shallow as $\sim 1 \mathrm{~m}$ beneath the sediment/water interface. At similar water depths, however, low methane and pyrite were found in some areas with almost no sulfate reduction.
\end{abstract}

\footnotetext{
${ }^{1}$ Institute of Oceanography, National Taiwan University, Taipei, Taiwan, ROC

2 Department of Geosciences, National Taiwan University, Taipei, Taiwan, ROC

${ }^{3}$ Central Geological Survey, MOEA, Taipei, Taiwan, ROC

* Corresponding author address: Prof. Saulwood Lin, Institute of Oceanography, National Taiwan University, Taipei, Taiwan, ROC; E-mail: swlin@ntu.edu.tw
} 
Sulfate flux in the study region is among the highest reported. Large spatial variations were a result of high methane flux, probably originating from gas hydrate deeper in sediments. Co-existence of rapid sulfate reduction and high methane concentrations in sediments indicated that methane is controlling sulfate reduction in the region. Downward diffusion of sulfate is linearly correlated with upward methane flux in the Good Weather Ridge region. Methane becomes an important source of carbon for the sulfate reducer and subsequently controlling sulfate reduction and pyrite formation.

(Key words: Sulfate reduction, Gas hydrate, Pyrite, Diffusion, South China Sea)

\section{INTRODUCTION}

Gas hydrate could be a major source of energy in the future considering the abundant 3600 GT of methane present on earth (Kvenvolden 1993; Collet and Kuuskraa 1998; Milkov et al. 2003). The potential of methane as a major future source of energy and as a mechanism in altering global climate have been the focus of intense scientific research (e.g., Kvenvolden 1988; MacDonald 1990). A number of geophysical and geochemical data indicates that gas hydrate may exist in the southwestern Taiwan continental margin sediments (Chi et al. 1998; Liu et al. 2003; Chao and You 2006; Chiu et al. 2006; Chuang et al. 2006; Horng and Chen 2006; Huang et al. 2006; Jiang et al. 2006; Liu et al. 2006; Oung et al. 2006; Shyu et al. 2006; Yang et al. 2006). Geophysical studies (Liu et al. 2004a; Chiu et al. 2006; Liu et al. 2006) of the Taiwan gas hydrate program showed that a strong Bottom Simulating Reflector (BSR) covered a large area of the southwestern Taiwan continental margin, indicating abundant gas hydrate exists in the sediments of the active continental margin near Taiwan.

Most gas hydrate appears deep beneath sediments under several hundreds to thousands of meters of water and sediment thus rendering direct study and sampling of gas hydrate a difficult task (Suess et al. 1999; Sassen et al. 2001; Milkov 2005). Sulfate reduction, chemosynthetic benthic communities, gas venting, formation of solid gas hydrate near the sea floor have all been used as important geochemical signals in investigating gas hydrate in marine environments (Boetius and Suess 2004; Sassen et al. 2004). In areas with gas hydrate, rapid sulfate reduction in sediments was found associated with high sulfide mineral formation (Arvidson et al. 2004). The close association of sulfate reduction and methane migration renders sulfate reduction and associated geochemical variations one of the most common approaches to studying gas hydrate in marine environments (Borowski et al. 1996; Joye et al. 2004). The purpose of this research is to investigate the effect of methane migration on sulfate reduction in the active margin sediments off southwestern Taiwan.

Sulfate reduction is a major pathway for organic carbon oxidation in marine sediments. In environments with higher concentrations of organic carbon or higher rates of deposition, such as the upwelling region of Namibia, Peru and northeast of Taiwan (Niewohner et al. 1998; Lin et al. 2002), higher rates of sulfate reduction and shallow sulfate/methane interface appears. In a 
normal marine environment, supply of organic carbon is the prime limiting factor for sulfate reduction in sediments (Berner 1984). With a limited supply of organic carbon from the water column, sulfate reduction in the normal marine sediments may take longer to complete (Berner 1980; Westrich and Berner 1984). Consequently, the sulfate/methane interface (SMI) may appear deeper in sediments. The appearance of gas hydrate and subsequently gaseous methane in marine sediments could provide additional organic carbon for sulfate reducing bacteria (Boetius et al. 2000; Orcutt et al. 2004). Borowski et al. (1999) showed that steep sulfatemethane gradients were found in marine sediments associated with gas hydrate and that methane could be another important source of organic carbon for sulfate reducing bacteria, resulting in a shallow sulfate/methane interface (SMI) and a rapid linear decrease of sulfate concentration in pore water. Aharon and $\mathrm{Fu}(2000)$ showed that sulfate reduction rates are anomalously higher in gas seeps sediments (up to a factor of 10) than in normal marine sediments supported by marine and terrigenous organic carbon at a similar water depth in the Gulf of Mexico. This close relationship between methane and sulfate concentrations makes sulfate reduction a useful proxy in understanding the degree of methane migration and the sulfate reduction process in marine environments (Borowski et al. 1996; Dickens 2001).

In this study, we investigated spatial variations of sulfate and methane concentrations in pore waters and the magnitude of pyrite formation in sediments in order to understand the effect and magnitude of methane migration on sulfate depletion in the Southwestern Taiwan continental margin and also the potential use of the sulfate-methane relationship as an indicator for gas hydrate prospecting in a marine environment.

\section{STUDY AREA AND METHODS}

\subsection{Study Area}

Offshore southwestern Taiwan is characterized by a series of anticline and faults with a trend switching from NNW-SSE, south of $22^{\circ} \mathrm{N}$ to NNE-SSW, north of $22^{\circ} \mathrm{N}$ (Liu et al. 1997). This deformation zone is located at the frontal edge of the accretionary wedge of the Luzon Arc and the China passive continental margin subduction-collision system (Liu et al. 2004b). The existence of a series of normal faults intersected by thrust faults in the accretionary prism off southwestern Taiwan may provide good conduits for gas and fluid venting upward to the surface. Mud volcanoes were reported on land by Yang et al. (2004) as well as on the sea floor (Chiu et al. 2006). The study area also receives a high flux of terrigenous suspended sediment exported from the adjacent Kaoping, Erjen and Tsengwen rivers with a combined average river particle load of $120 \mathrm{MT} \mathrm{yr}^{-1}$ (Dadson et al. 2003).

\subsection{Sampling}

In order to study spatial variations of sulfate reduction rates and methane concentrations in the study area, a total of 30 piston cores and 78 gravity cores were taken from the Good Weather Ridge area (Fig. 1) on R/V OR-I $(697,718,732)$ and II $(1207,1230)$. Sediment samples were immediately sliced every $2 \mathrm{~cm}$ into plastic centrifuge tubes for pore water and 


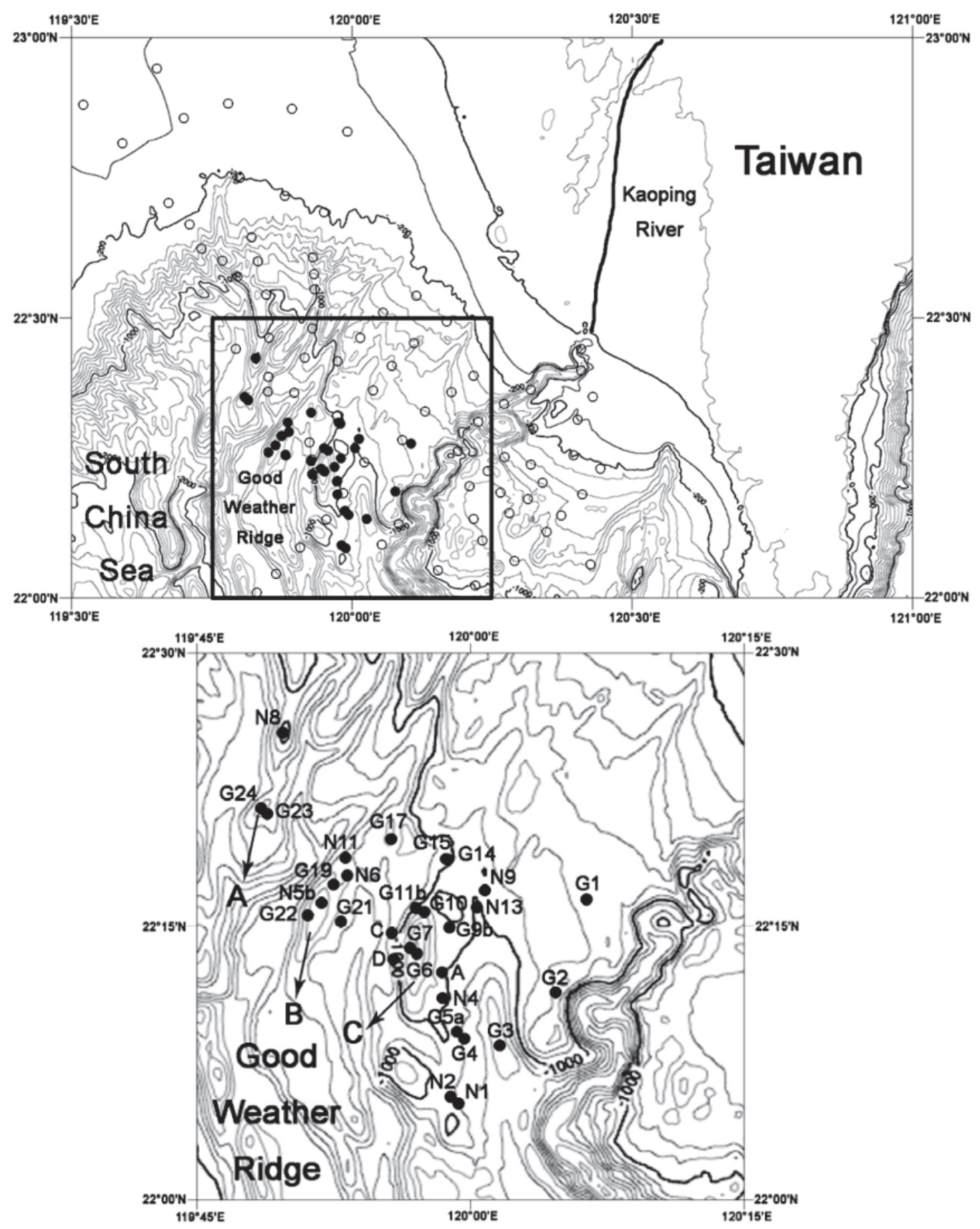

Fig. 1. Sampling sites offshore of southwestern Taiwan (open circles: gravity cores, black circles: piston cores). Good Weather Ridge A, B and C are arbitrarily assigned. 
solid phase analyses on board. Part of the sliced sediments samples were centrifuged, filtered through a $0.45 \mu \mathrm{m}$ polycarbonate syringe filter and later analyzed using the methylene blue method (Cline 1969) for dissolved sulfide. Remaining filtered pore water samples were stored in plastic vials for dissolved sulfate measurement on land. Portions of the sediment samples were stored in plastic tubes at $4^{\circ} \mathrm{C}$ for further analysis.

\subsection{Analytical Methods}

Pore water sulfate concentrations were determined by ion chromatography (O'Dell et al. 1984; Lin et al. 2002) with a Dionex 4500i ion chromatograph equipped with a conductivity detector and an IonPac AS4A anion exchange column. Pore water samples were usually diluted 80 -fold prior to analysis. $1.7 \mathrm{mM} \mathrm{NaHCO}_{3}$ and $1.8 \mathrm{mM} \mathrm{Na}_{2} \mathrm{CO}_{3}$ were used as the eluent and $0.025 \mathrm{~N} \mathrm{H}_{2} \mathrm{SO}_{4}$ as the regeneration fluid.

Total carbon and organic carbon were analyzed with a LECO C/S analyzer (SC-444) equipped with a high temperature resistance furnace and an IR detector. Approximately $0.3 \mathrm{~g}$ of dry sediment was combusted at $1400^{\circ} \mathrm{C}$ with high purity oxygen to determine the total carbon content. Sediment was pre-acidified $(\sim 50 \mathrm{ml} 2 \mathrm{~N} \mathrm{HCl}, 4 \mathrm{hr})$ and rinsed with de-ionized water several times to remove acid. Organic carbon was determined after drying the acidified samples. Calcium carbonate content (wt\%) was calculated from the difference between total carbon and organic carbon assuming that calcite was the only carbonate phase.

Pyrite-sulfur was determined by the $\mathrm{Cr}$ (II) $+6 \mathrm{~N} \mathrm{HCl}$ extraction method, and acid volatile sulfide (AVS) was measured by the cold 6N HCl extraction technique (Canfield et al. 1986; Cornwell and Morse 1987; Lin et al. 2002).

Methane concentration in pore water was collected on board by the headspace method and analyzed with gas chromatography (GC-SRI 8610C) (Chuang et al. 2006). After approximately $350 \mathrm{~cm}^{3}$ of wet sediment was filled into a $930 \mathrm{~cm}^{3}$ tin container, the tin can was filled with deionized water $(\sim 18 \Omega)$ until $30 \mathrm{~cm}^{3}$ of headspace remained. $\mathrm{HgCl}_{2}$ was added to poison bacteria activity. The tin can was caped, sealed with silicone to prevent leaking, and stored at $4^{\circ} \mathrm{C}$ until measurement. The headspace gas was collected by a syringe and later injected into a gas chromatograph for gas composition measurement.

\section{RESULTS}

\subsection{Organic Carbon Concentrations in Sediment}

Organic carbon concentrations (Fig. 2) in sediments are relatively low in the study region, within the range of 0.1 to $1.0 \mathrm{wt} \%$, with an average concentration of $0.46 \pm 0.20 \%$ ( $\mathrm{n}=118)$. In general, organic carbon concentrations increased from shelf to slope in the study region. For shelf sediments in the northern part of the study region, organic carbon concentrations are lowest, less than $0.2 \%$. In shelf areas near coastal Taiwan, concentrations are slightly higher, but not more than $0.5 \%$. In the slope region, organic carbon concentrations are relatively high, within 0.4 to $1.0 \%$, with the highest appearing in a region west of the Kaoping Canyon at water depth between 200 to $800 \mathrm{~m}$. 


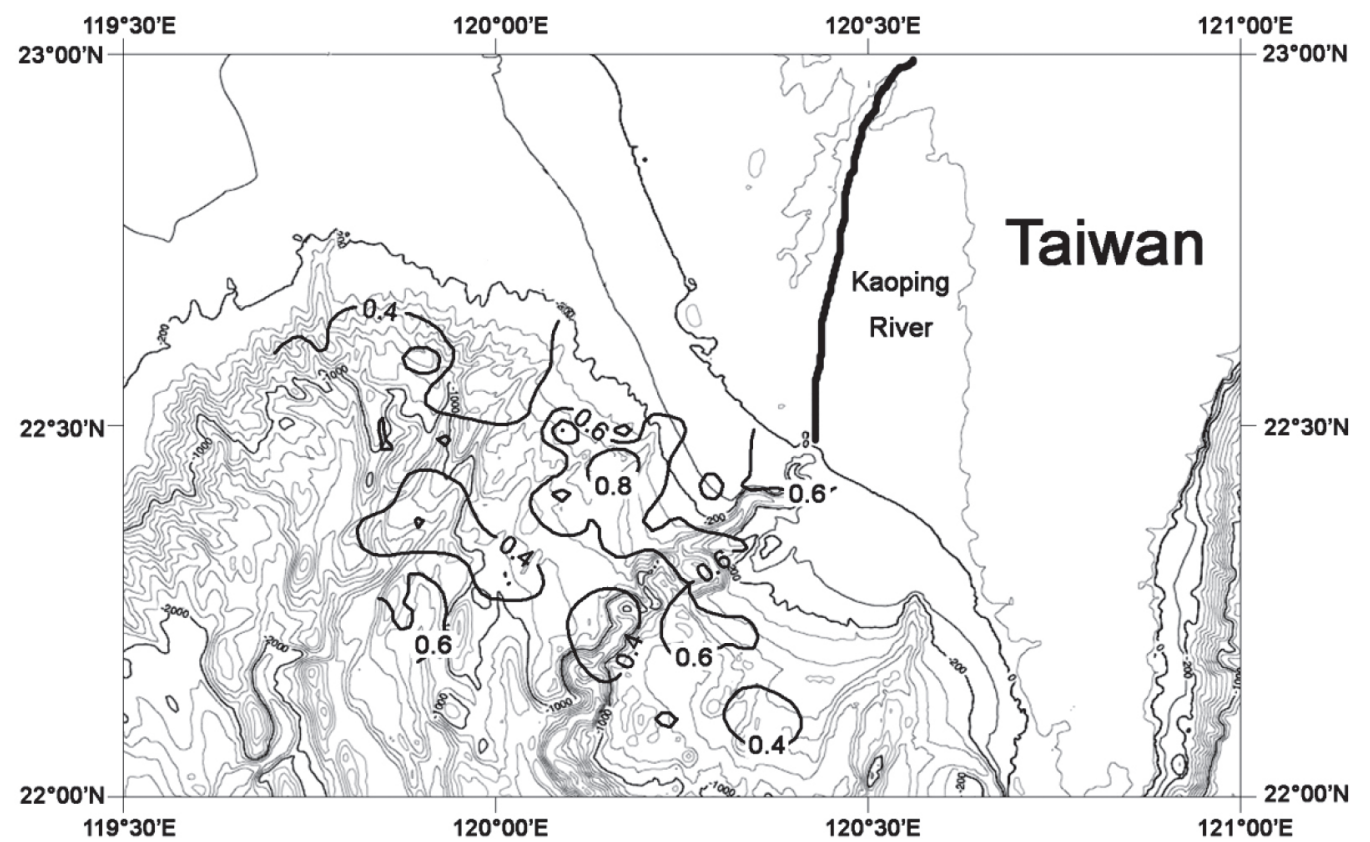

Fig. 2. Spatial variations of organic carbon concentrations (\%) in the study region surface sediments.

Three types of vertical variations in organic carbon concentration were observed in the studied stations (Fig. 3). Some showed almost no variations with depth (e.g., stations G24, N6, G6, N4, N13, G3, G1) and some showed slight decrease with increasing depth (G22, N8, N11, D, C, A, G5A) while a few stations showed slight fluctuations near the top of the core (G21, G22, N11, G14, N4, N13, N9, N2).

\subsection{Sulfate and Dissolved Sulfide Concentrations in Pore Water}

Sulfate concentrations in the pore water collected in the study area showed clear vertical variations with depth (Fig. 4). Rapid sulfate reduction were observed at some stations with the complete depletion of sulfate within $1 \mathrm{~m}$ beneath the sediment/water interface while almost no sulfate reduction was observed in pore water collected from some stations. At stations with rapid sulfate reduction, higher methane concentrations were also found. At the sediment/water interface in the study area, typical seawater sulfate concentration of about $29 \mathrm{mM}$ was observed. At depth, large variations in sulfate concentrations were found. Three types of sulfate depletion were observed as depth increased: rapid exponential sulfate depletion (e.g., stations G21, G22, G23, N8, G19, N6, G14, G5a, G9b, N1, G3); linear sulfate depletion (e.g., stations G24, 

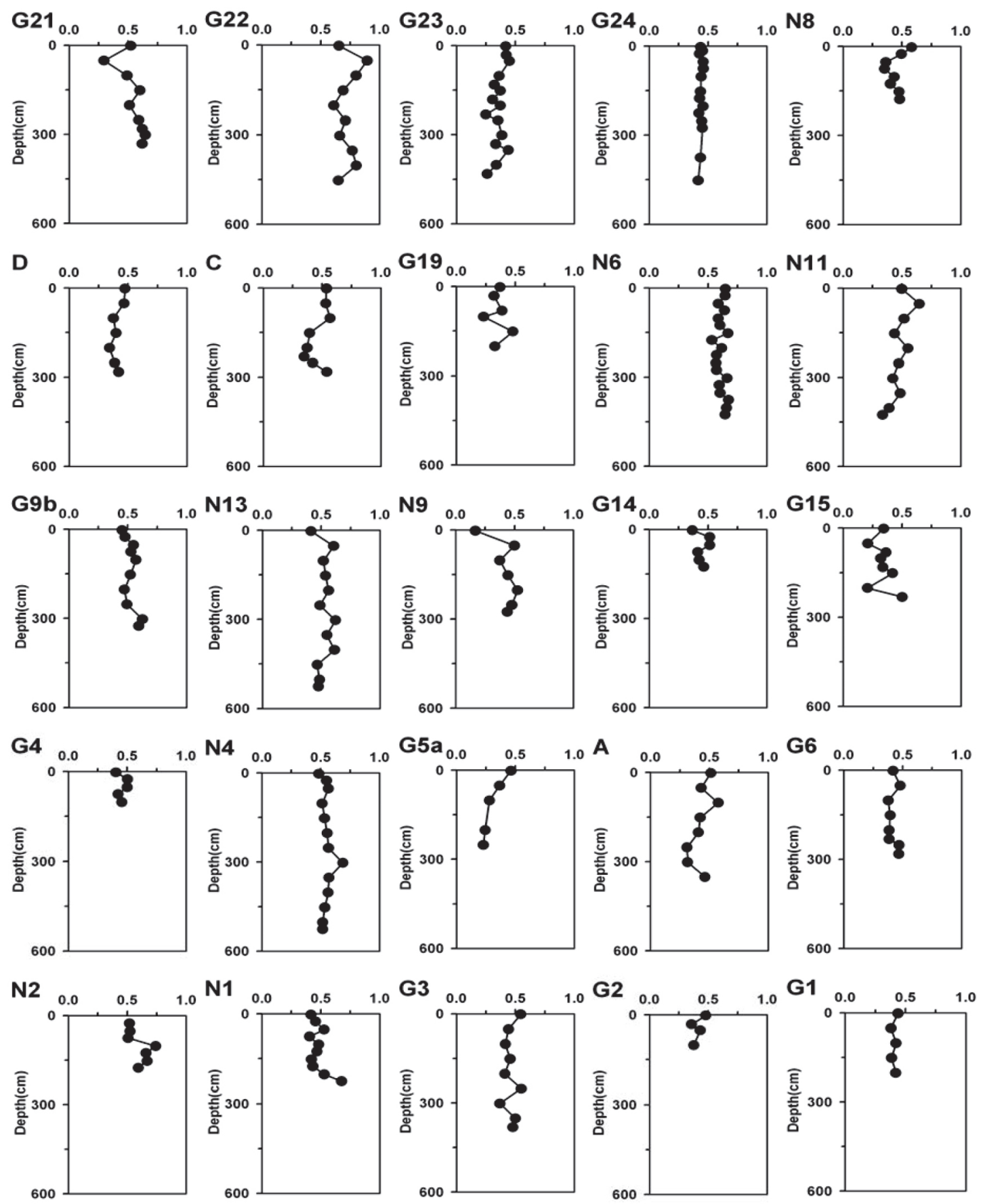

Fig. 3. Vertical organic carbon concentrations (\%) variations in the study region piston core samples. 

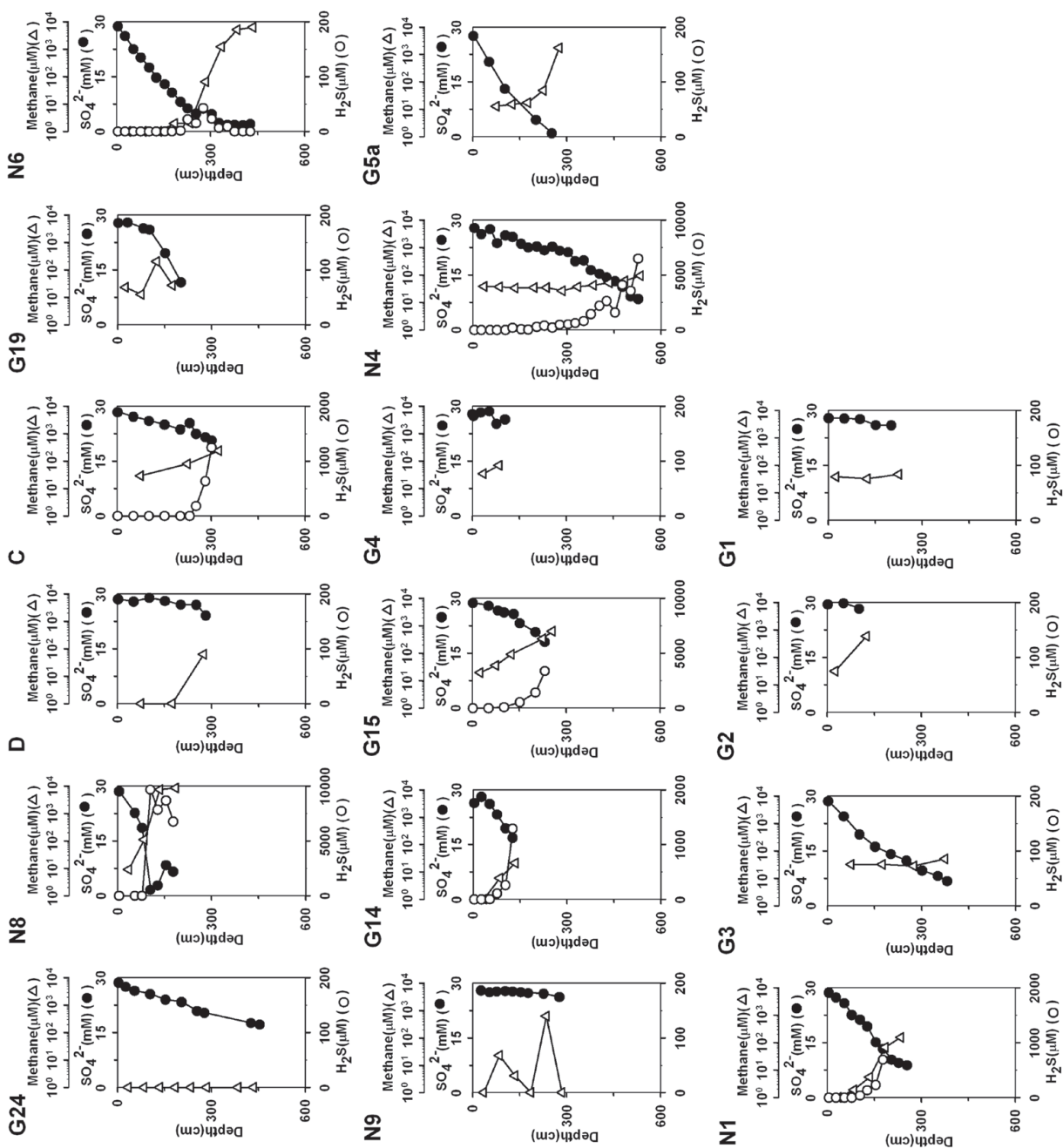

氖
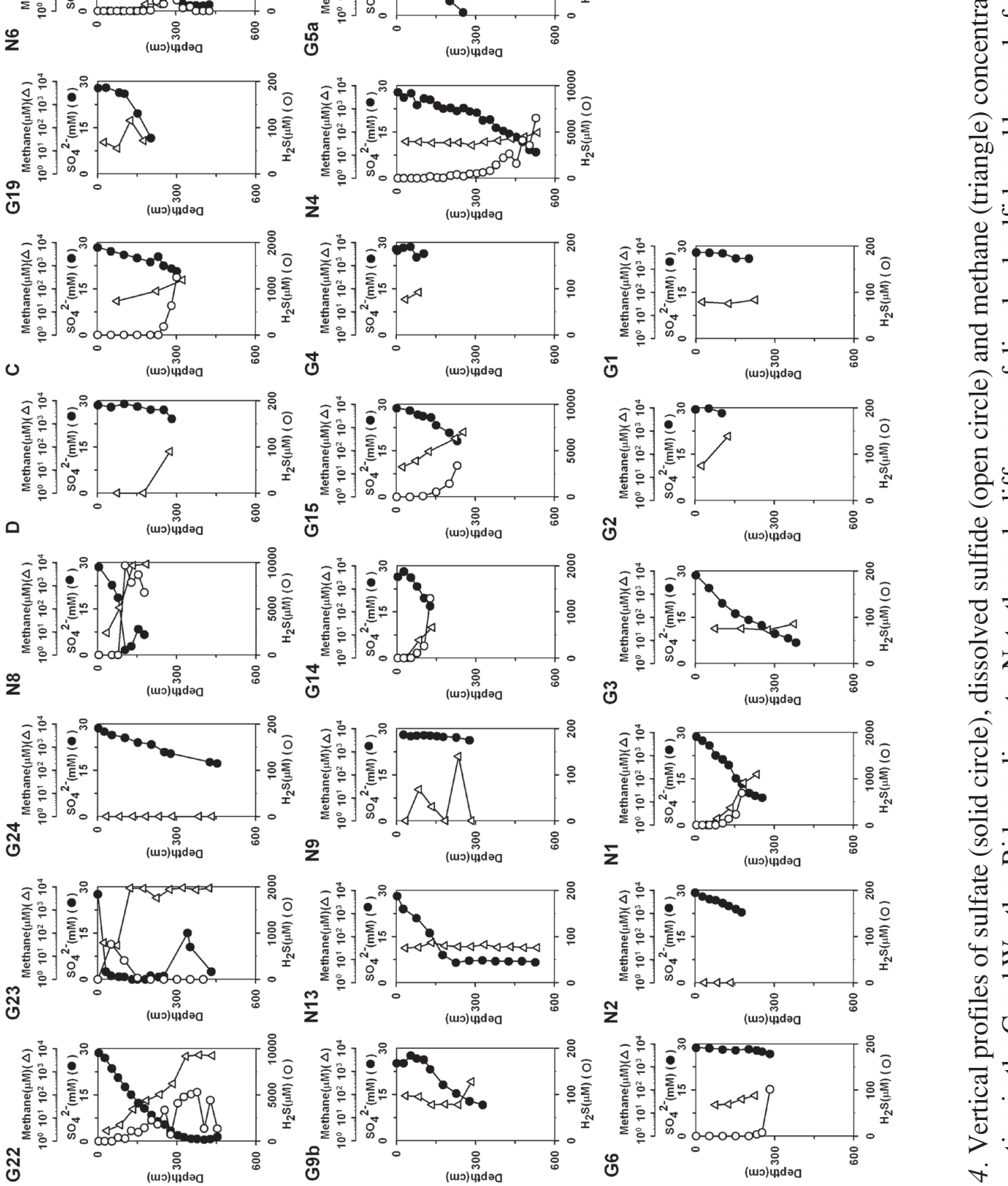

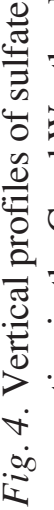

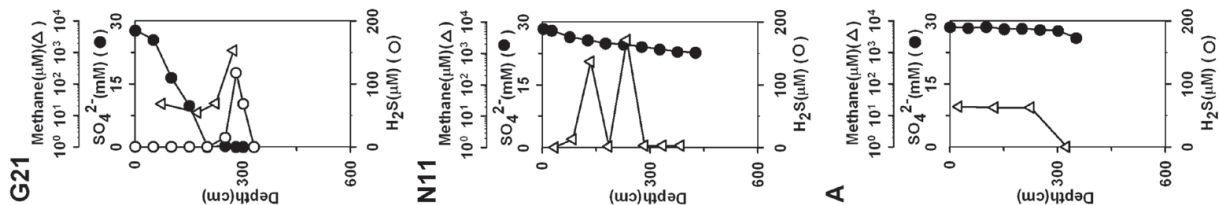


N11, C, G15, N4, N2); and no sulfate depletion (e.g., stations D, A, G6, N9, G1). The observed shallow sulfate/methane interface at a depth of $\sim 1 \mathrm{~m}$ indicated that methane is readily available for the sulfate reducing bacteria in our study environment and also play an important role in determining the degree of sulfate reduction. This is unlike the rapid sulfate depletion commonly observed in shallow water environments (e.g., Jorgensen 1982; Lin and Morse 1991; Lin et al. 2002) where organic carbon in sediments is the primary source of energy for the sulfate reducer.

Dissolved sulfide concentrations in the pore water also showed large spatial and vertical variations in this study region (Fig. 4). Dissolved sulfide subsurface maximum appeared at depths where sulfate were reduced to a lower concentration. However, in pore water from some stations, both dissolved sulfate and sulfide co-existed and that dissolved sulfide appeared even at depths where sulfate concentrations remained relatively high (e.g., stations G23, G6, C, G14, G15, G6, N4, N1). Furthermore, in pore water from some stations, dissolved sulfide was detected at depths where there was very low sulfate depletion (e.g., station G6). Dissolved sulfide subsurface maximum, as high as $10 \mathrm{mM}$, appeared at a depth of 1 to 3 meters below the sediment/water interface. Although dissolved sulfide concentrations gradually decrease to below the detection limit (e.g., stations G23, N6), a large number of stations exhibited sulfide concentrations that continuously increased with depth (Station G21, G23, N8, C, G14, G15, G6, N4, N1).

\subsection{Methane Concentrations in Pore Water}

High concentrations of methane in pore waters were observed in the study region (Fig. 4). The highest concentrations reached $9.2 \mathrm{mM}$ at Station G23 at a depth of $\sim 150 \mathrm{~cm}$ beneath the sediment/water interface. However, large differences existed both vertically and spatially. Methane concentrations were low in general, mostly below detection limit beneath the sediment/water interface until a subsurface maximum was found at depth, which varied, from as shallow as $1 \mathrm{~m}$ beneath the sediment/water interface at Station N8 to greater than 6 meters, the maximum length of our core. High concentrations of methane beneath a zone of rapid sulfate depletion indicate that sulfate reduction is an important mechanism in oxidizing methane. In addition, high concentrations of methane were observed at depth above the total sulfate depletion zone at some stations (G23, C, G14, G15, G6, N4, N1). Detailed methane variations were described in Chuang et al. (2006) and Yang et al. (2006).

\subsection{Pyrite-S Concentrations in Sediments}

Large vertical and spatial pyrite-S concentration variations were observed in the study area (Fig. 5). For stations with little sulfate reduction, low concentrations of pyrite-S were found in the surface sediments as well as the deeper sections of each core (stations N11, N9). Pyrite-S concentrations increased with increasing depth as a result of sulfate reduction (stations G21, G24, N8, N6, D, C, G14, G15, A, G9b, G4, N4, N13, G1). Unusually high pyrite-S concentrations were found in stations G22, G23, and G6 where rapid sulfate reduction and high concentrations of methane were found. 

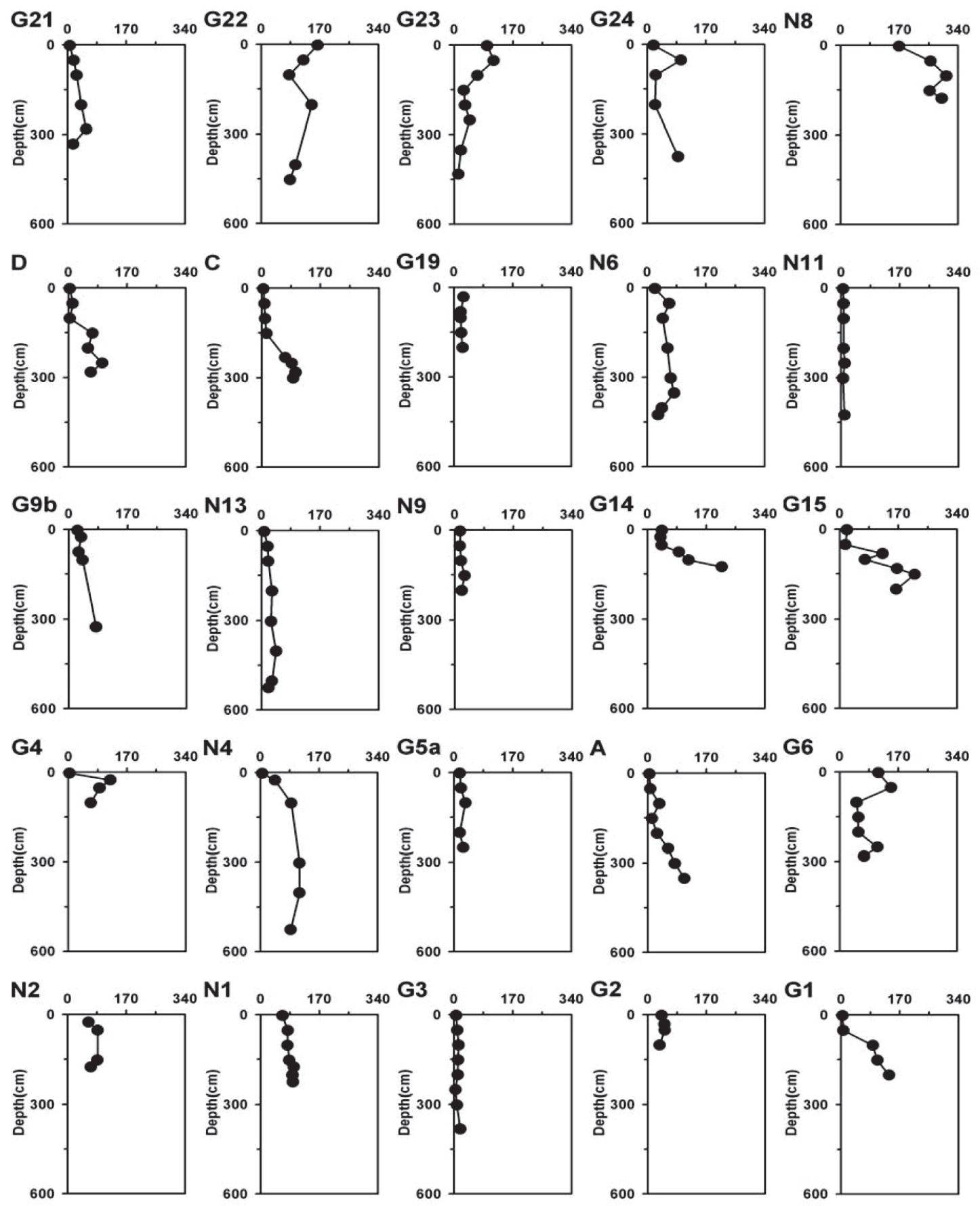

Fig. 5. Vertical pyrite-S concentration variations in piston cores samples in the Good Weather Ridge region (unit in $\mu \mathrm{mol} \mathrm{g}^{-1}$ ). 


\section{DISCUSSION}

Organic carbon is the source of energy for sulfate reducing bacteria. Major sources of organic carbon include organic carbon deposition from the upper water column and methane diffusion upward. In normal marine sediments, the primary source of organic carbon for sulfate reducing bacteria originates from the upper column. The amount of organic carbon reaching the seafloor is a function of water depth and productivity (Suess 1980). With the exception of anoxic basin where organic carbon is better preserved, organic carbon is usually the primary limiting factor for sulfate reduction in most continental margin sediments (Berner 1982). In environments where gas hydrate exists, the supply of methane from gas hydrate deep in the sediment may provide an additional source of carbon for the sulfate reducer (Reeburgh 1980; Hoehler et al. 1994). Sulfate reduction could use both organic carbon and methane as the carbon source.

$$
\begin{aligned}
& 2\left(\mathrm{CH}_{2} \mathrm{O}\right)+\mathrm{SO}_{4}^{2-} \rightarrow 2 \mathrm{HCO}_{3}^{1-}+\mathrm{H}_{2} \mathrm{~S}, \\
& \mathrm{CH}_{4}+\mathrm{SO}_{4}^{2-} \rightarrow \mathrm{HCO}_{3}^{1-}+\mathrm{HS}^{1-}+\mathrm{H}_{2} \mathrm{O} .
\end{aligned}
$$

Sulfate was used during oxidation of carbon with the production of dissolved sulfide and bicarbonate. Dissolved sulfide reacts with iron with pyrite being the end product (Berner 1984). Consequently, abundant pyrite may occur in sediments associate with methane from gas hydrate dissociation and migrate upward to the sulfate reduction zone (Arvidson et al. 2004).

\subsection{Unusual Sulfate Reductions}

In the Good Weather Ridge system, organic carbon concentrations in the study region surface sediments showed a good linear negative relationship with respect to water depth (Fig. 6a). Organic carbon concentrations decreased from shelf to slope as water depth increased. In addition, organic carbon concentrations were relatively low, within 0.25 to $0.75 \%$. Given the limited supply of organic carbon, pyrite formation would be limited and less pyrite would be expected. However, for sediments in water depth between 500 to $1500 \mathrm{~m}$, unusually high concentrations of pyrite were observed as compared to lower concentrations of pyrite in deep water and shallower water sediments (Fig. 6b). Pyrite concentrations were as high as $\sim 300 \mu \mathrm{mol} \mathrm{g}^{-1}$ as compared to $\sim 20 \mu \mathrm{mol} \mathrm{g}^{-1}$ in stations with limited sulfate reduction. High concentrations of pyrite, dissolved sulfide as well as methane were found in stations with very rapid sulfate depletion (Fig. 5). In addition to high pyrite concentrations found in areas with high methane content, the sulfate/methane interface was as low as $1 \mathrm{~m}$ beneath the sediment/water interface. However, rapid sulfate reduction in some stations did not correlate with organic carbon concentration typically observed in normal marine environments (Lin and Morse 1991; Lin et al. 2002). In fact, the unusually high pyrite concentrations and extremely high dissolved sulfide in sediments at water depths between 500 to $1500 \mathrm{~m}$ indicated that an extra source of carbon existed in the study area to support the observed rapid sulfate reduction and subsequent pyrite formation. 


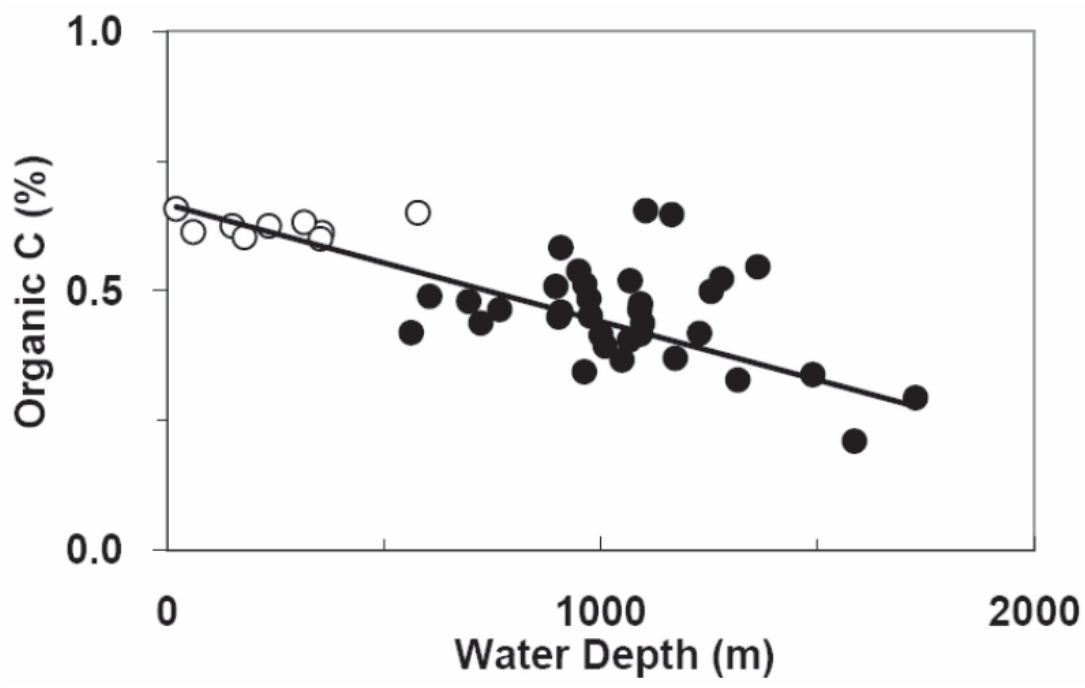

Fig. 6a. Relationship between surface sediments organic carbon concentration and water depth. Solid circles are sampling sites at Good Weather Ridge, open circles are on the shelf. Linear correlation coefficient $\left(\mathrm{r}^{2}\right)$ is 0.736 .

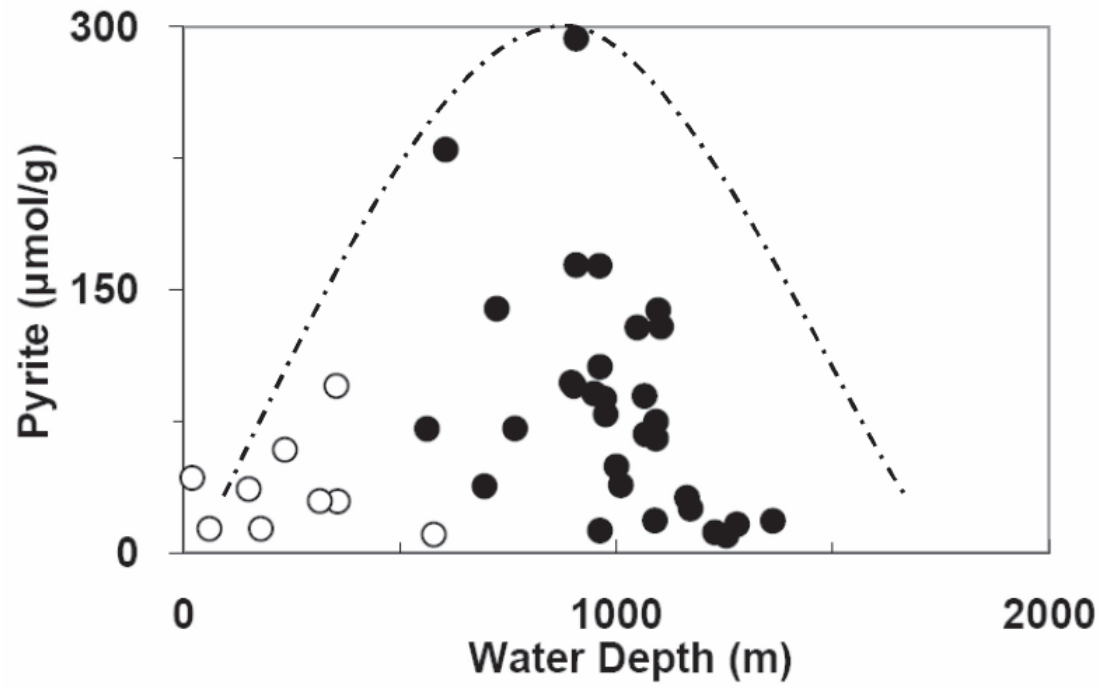

Fig. 6b. Variations of sediment pyrite-S concentrations with respect to the overlying water depth. Dashed line showing unusually high pyrite concentrations for water depths within 800 to $1200 \mathrm{~m}$. Solid circles are sampling sites at Good Weather Ridge, open circles are on the shelf. 
Unusually high rates of sulfate reduction were also found in other studies with a high methane concentration. Aharon and $\mathrm{Fu}(2000)$ showed anomalously high sulfate reduction rates in sediments at gas-seep areas in the Gulf of Mexico as compared to normal marine sediments. Borowski et al. (1999) also showed that steep sulfate-methane gradients were found in marine sediments associated with gas hydrate. Additionally, they also showed that methane could be another important source of organic carbon for sulfate reducing bacteria, resulting in shallow sulfate/methane interface (SMI) and a rapid linear decrease of sulfate in pore water. The appearance of unusually high rates of sulfate reduction at an area without higher concentrations of organic carbon coupled with the close association with high methane contents clearly demonstrates that high methane contents found in the Good Weather Ridge sediments are another source of carbon for the observed higher sulfate reduction rate.

\subsection{Sulfate and Methane Flux}

Fossing et al. (2000) and Dickens (2001) showed that fluxes of sulfate reduction and methane are closely associated in environments where gas hydrate exists. In order to better describe the relationship between sulfate reduction and methane flux in the Good Weather Ridge system, fluxes of downward sulfate and upward methane are calculated using Fick's diffusion equation:

$$
F_{i}=-\phi D \frac{\partial C_{i}}{\partial z}
$$

Diffusion coefficients in sediments are calculated based on Li and Gregory (1974) and using Iverson and Jorgensen (1993) equation:

$$
D=\frac{D o}{1+n(1-\phi)},
$$

where $F_{i}$ is flux of sulfate or methane across a horizon at depth $z ; \phi$ is porosity; $D$ is the diffusion coefficient of sulfate or methane in sediment; $C_{i}$ is the concentration of sulfate or methane at a particular horizon of depth $z$; Do is $0.87 \times 10^{-5} \mathrm{~cm}^{2} \mathrm{sec}^{-1}$ and $0.56 \times 10^{-5} \mathrm{~cm}^{2} \mathrm{sec}^{-1}$ for methane and sulfate; and $n=3$ for muddy sediments (Iversen and Jorgensen 1993).

Methane and sulfate flux in the study region are in the ranges of $0.01-87$ and $1.08-219$ mmole $\mathrm{m}^{-2} \mathrm{yr}^{-1}$, respectively (Table 1). Sulfate and methane flux are among the highest reported and much higher than those in the Blake Ridge (Dickens 2001; Borowski et al. 1999) or Argentine basin (Hensen et al. 2003) but slightly lower than those in the eastern North Pacific (Brelson et al. 2005). Berelson et al. (2005) showed that high sulfate flux at the California Borderland, eastern North Pacific was attributed to a high organic carbon oxidation rate and high methane flux diffused into the sulfate reduction zone.

Fluxes of methane and sulfate are also plotted in Figs. 7a and b. Diffusion flux of sulfate and methane show large variations in the study area. Both sulfate and methane flux showed 
higher fluxes at some stations at depths ranging from 750 to $1500 \mathrm{~m}$. High sulfate and methane fluxes occurring at the same stations indicate that downward diffusion sulfate fluxes are supported by the upward diffusion of methane fluxes. In fact, downward sulfate flux is positively correlated with the upward methane flux (Fig. 8). With more methane diffusing upward, more sulfate was consumed in sediments. Consequently, more dissolved sulfide and pyrite were produced.

The slope of sulfate flux versus methane flux is about 2 (Fig. 8), which indicates that the sulfate flux is 2 times higher than methane flux based on equation 2 . If methane is the only source of carbon, the amount of methane consumed should equal that provided by sulfate. Although the observed $1: 2$ ratio could indicate an excess consumption of sulfate in the study area, a more plausible explanation is the underestimation of the methane flux as a result of our gas sampling procedure. Methane could dissipate during coring operations without using a pressure core. Although extra precautions were taken in gas sampling, a major portion of methane could have escaped before retrieving core samples on board and prior to sampling into sampling containers. As a result, methane flux could potentially be significantly underestimated.

At stations with lower methane flux, sulfate deviate slightly from the trend, probably a result of high organic carbon deposition at these stations with low methane flux. Berelson et al. (2005) also showed that both high organic carbon oxidation and rapid methane oxidation contributed to higher sulfate flux in the North Pacific region. Under low methane flux conditions, organic carbon deposition becomes the prime factor and thus slight deviations from the observed trend.

Table 1. Methane and sulfate flux in different environments.

\begin{tabular}{llll}
\hline Area & $\begin{array}{l}\text { Methane flux } \\
\left(\mathrm{mmole} / \mathrm{m}^{2} / \mathrm{yr}\right)\end{array}$ & $\begin{array}{l}\text { Sulfate flux } \\
\left(\mathrm{mmole} / \mathrm{m}^{2} / \mathrm{yr}\right)\end{array}$ & Reference \\
\hline $\begin{array}{l}\text { Good Weather Ridge, } \\
\text { southwestern Taiwan }\end{array}$ & $0.01-87.0$ & $1.80-219$ & This study \\
$\begin{array}{l}\text { E. North Pacific } \\
\text { W. Argentine Basin }\end{array}$ & -- & $164-475$ & Berelson et al. (2005) \\
$\begin{array}{l}\text { Black Ridge, Atlantic } \\
\text { Calif. Rise and Blake }\end{array}$ & -- & $1.01-162$ & Hensen et al. (2003) \\
Ridge, Atlantic & & $7.90-8.60$ & Dickens (2001) \\
$\begin{array}{l}\text { Namibia, } \\
\text { E. South Atlantic }\end{array}$ & $24.3-51.7$ & $21.5-61.5$ & Niewohner et al. (1998) \\
\hline
\end{tabular}




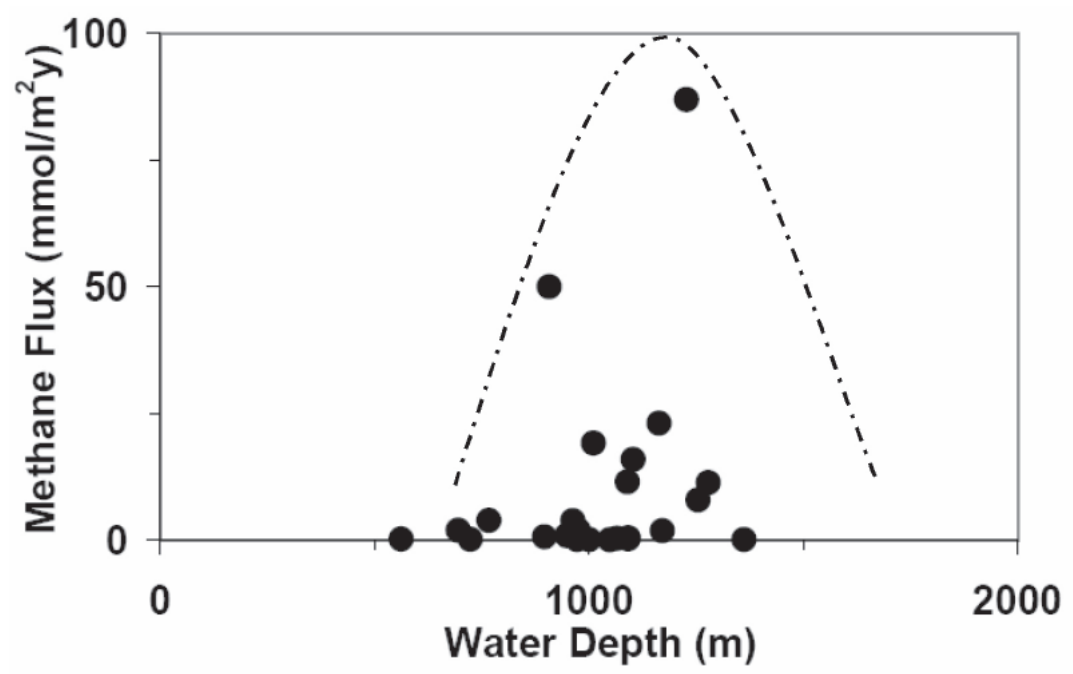

Fig. 7a. Sediment methane flux variation with respect to overlying water depth. Dashed line showing unusually high methane flux for those in water depths ranging from 800 to $1200 \mathrm{~m}$. Solid circles are sampling sites at Good Weather Ridge, open circles are on the shelf.

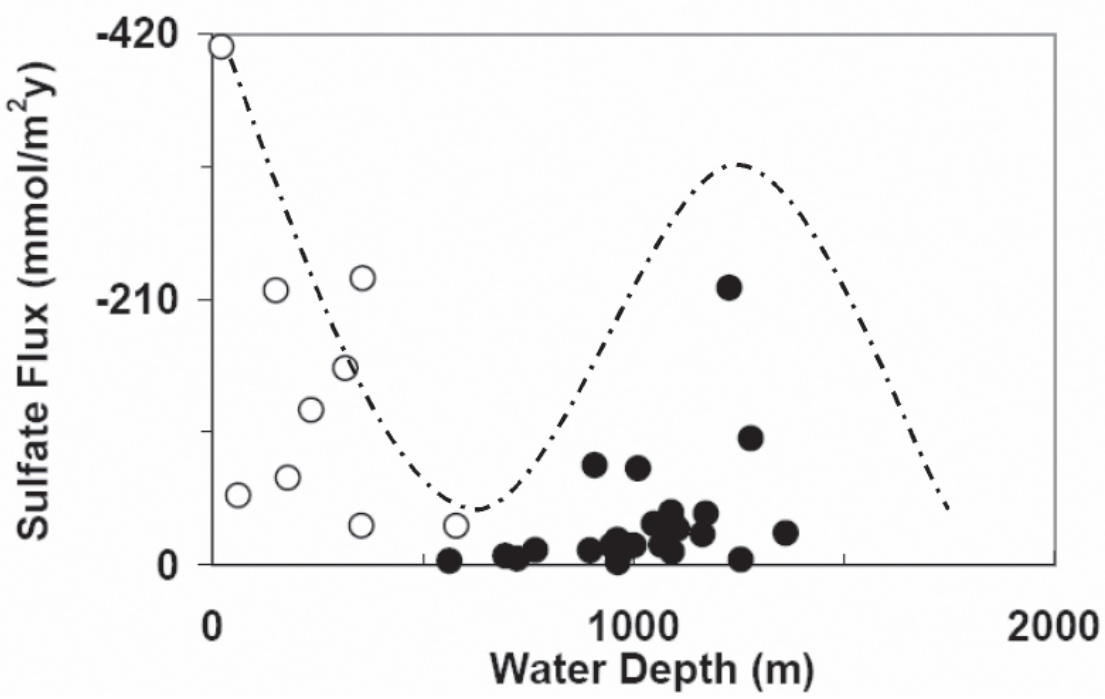

Fig. 7b. Sediment sulfate flux variation with respect to overlying water depth. Dashed line showing unusually high methane flux for those in water depths ranging from 800 to $1200 \mathrm{~m}$. Solid circles are sampling sites at Good Weather Ridge, open circles are on the shelf. 


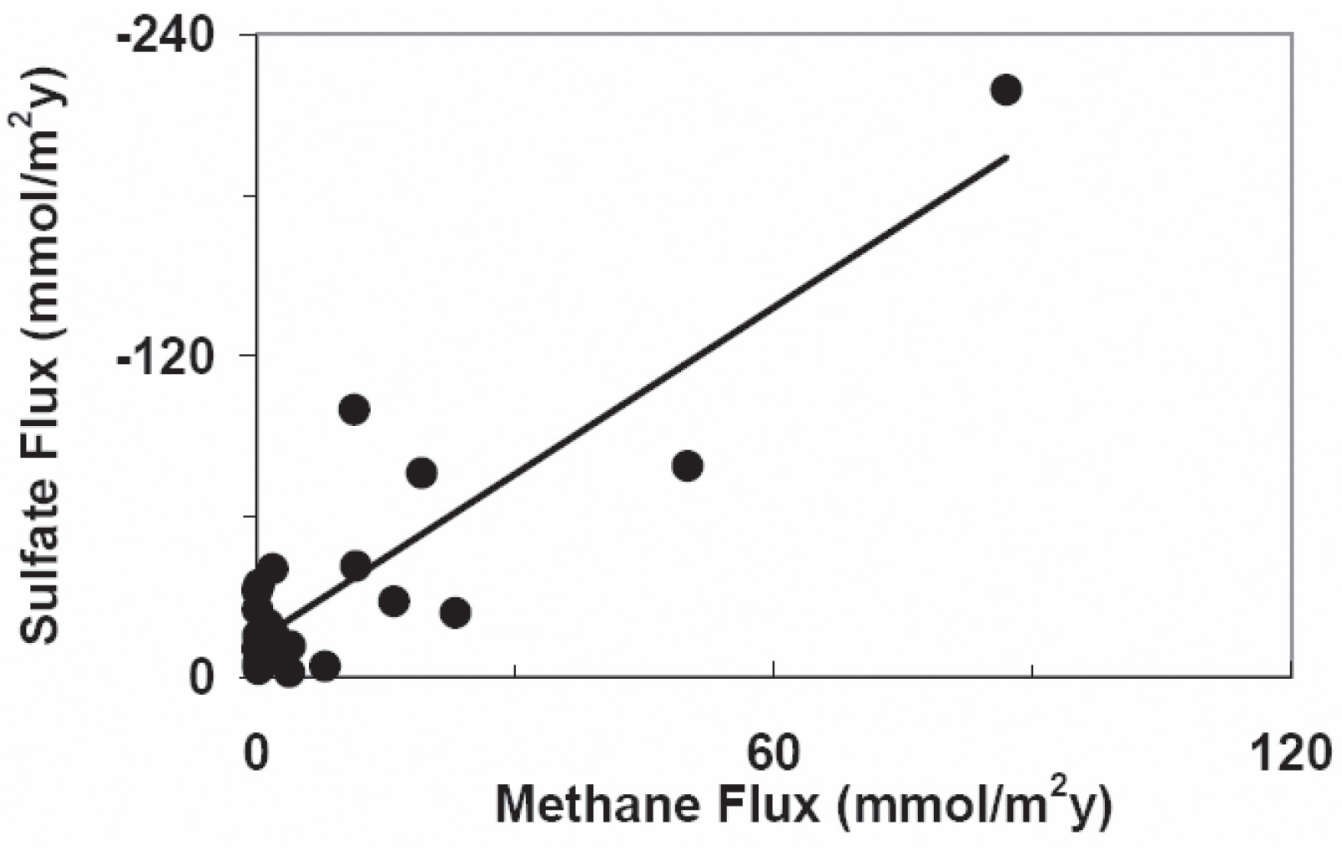

Fig. 8. Relationship between sulfate flux and methane flux; correlation coefficient $\left(r^{2}\right)$ is 0.778 .

\section{CONCLUSION}

Good Weather Ridge in the Southwestern Taiwan continental margin is characterized by rapid sulfate reduction and high methane contents in sediments. Methane diffusing upward becomes an important source of carbon for observed rapid sulfate reduction in the region.

Sulfate reduction varied vertically and spatially in the study region with some sites showing complete sulfate depletion within a meter beneath the sediment/water interface whereas some areas showed very little depletion. High concentrations of methane were also found at a number of stations where rapid sulfate depletion was found. In areas with almost no sulfate reduction, methane concentrations were also low. In areas with rapid sulfate reduction, unusually high pyrite concentrations, up to $300 \mu \mathrm{mol} \mathrm{g}^{-1}$ of pyrite, and high dissolved sulfide, up to $10 \mathrm{mM}$, were observed.

A large degree of variation in sulfate reduction depends on the upward diffusion of methane. A good linear correlation between downward sulfate flux and upward methane flux was found in the study region. Methane diffusing into the sulfate reducing zones provides additional carbon for the sulfate reducer and consequently induces fast sulfate reduction and unusual pyrite formation. 
Acknowledgements We thank reviewers for their constructive comments and detailed suggestions, which improved our manuscript significantly. Financial supports from the Central Geological Survey, MOEA made this study possible. Special thanks go to Dr. J. C. Chen for his logistic support. We would also like to thank the students and research assistants for their efforts on the sampling cruises during the course of this research.

\section{REFERENCES}

Aharon, P., and B. Fu, 2000: Microbial sulfate reduction rates and sulfur and oxygen isotope fractionations at oil and gas seeps in deepwater Gulf of Mexico. Geochim. Cosmochim. Acta, 64, 233-246.

Arvidson, R. S., J. W. Morse, and S. B. Joye, 2004: The sulfur biogeochemistry of chemosynthetic cold seep communities, Gulf of Mexico, USA. Mar. Chem., 87, 97-119.

Berelson, W. M., M. Prokopenko, F. J. Sansone, A. W. Graham, J. MaManus, and J. M. Bernhard, 2005: Anaerobic diagenesis of silica and carbon in continental margin sediments: discrete zones of $\mathrm{TCO}_{2}$ production. Geochim. Cosmochim. Acta, 69, 46114629.

Berner, R. A., 1980: Early Diagenesis: A theoretical Approach, Princeton University Press, $241 \mathrm{pp}$.

Berner, R. A., 1982: Burial of organic carbon and pyrite sulfur in the modern ocean: its geochemical and environmental significance. Am. J. Sci., 278, 451-473.

Berner, R. A., 1984: Sedimentary pyrite formation: an update. Geochim. Cosmochim. Acta, 48, 605-615.

Boetius, A., K. Ravenschlag, C. J. Schubert, D. Rickert, F. Widdel, A. Gieseke, R. Amann, B. B. Jørgensen, U. Witte, and O. Pfannkuche, 2000: A marine microbial consortium apparently mediating anaerobic oxidation of methane. Nature, 407, 623-626.

Boetius, A., and E. Suess, 2004: Hydrate Ridge: a natural laboratory for the study of microbial life fueled by methane from near-surface gas hydrate. Chem. Geol., 205, 291-310.

Borowski, W. S., C. K. Paull, and W. Ussler III, 1996: Marine pore water sulfate profiles indicate in situ methane flux from underlying gas hydrate. Geology, 24, 655-658.

Borowski, W. S., C. K. Paull, and W. Ussler III, 1999: Global and local variations of interstitial sulfate gradients in deep-water, continental margin sediments: sensitivity to underlying methane and gas hydrates. Mar. Geol., 159, 131-154.

Canfield, D. E., R. Raiswell, J. T. Westrich, C. M. Reaves, and R. A. Berner, 1986: The use of chromium reduction in the analysis of reduced inorganic sulfur in sediments and shales. Chem. Geol., 54, 149-155.

Chao, H. C., and C. F. You, 2006: Distribution of B, Cl and their isotopes in pore waters separated from gas hydrate potential areas, offshore southwestern Taiwan. Terr. Atmos. Ocean. Sci., 17, 961-979.

Chi, W. C., D. L. Reed, C. S. Liu, and N. Lunberg, 1998: Distribution of the bottom simulating reflector in the offshore Taiwan Collision Zone. Terr. Atmos. Ocean. Sci., 9, 779-793. 
Chiu, J. K., W. H. Tseng, and C. S. Liu, 2006: Distribution of gassy sediments and mud volcanoes offshore southwestern Taiwan. Terr. Atmos. Ocean. Sci., 17, 703-722.

Chuang, P. C., T. F. Yang, S. Lin, H. F. Lee, T. F. Lan, W. L. Hong, C. S. Liu, J. C. Chen, and Y. Wang, 2006: Extremely high methane concentration in bottom water and cored sediments from offshore southwestern Taiwan. Terr. Atmos. Ocean. Sci., 17, 903-920.

Cline, J. D., 1969: Spectrophotometric determination of hydrogen sulfide in natural waters. Limnol. Oceanogr., 14, 454-458.

Collett, T. S., and V. A. Kuuskraa, 1998: Hydrates contain vast store of world gas resources. Oil Gas J., 96, 90-95.

Cornwell, J. C., and J. W. Morse, 1987: The characterization of iron sulfide minerals in marine sediments. Mar. Chem. 22, 193-206.

Dadson, S. J., N. Hovius, H. Chen, W. B. Dade, M. L. Hsieh, S. D. Willett, J. C. Hu, M. J. Horng, M. C. Chen, C. P. Stark, D. Lague, and J. C. Lin, 2003: Links between erosion, runoff variability and seismicity in the Taiwan orogen. Nature, 426, 648-651.

Dickens, G. R., 2001: Sulfate profiles and barium fronts in sediment on the Blake Ridge: present and past methane fluxes through a large gas hydrate reservoir. Geochim. Cosmochim. Acta, 65, 529-543.

Fossing, H., T. G. Ferdelman, and P. Berg, 2000: Sulfate reduction and methane oxidation in continental margin sediments influcenced by irrigation (South-East Atlantic off Namibia). Geochim. Cosmochim. Acta, 64, 897-910.

Hensen, C., M. Zabel, K. Pfeifer, T. Schwenk, S. Kasten, N. Riedinger, H. D. Schulz, and A. Boetius, 2003: Control of sulfate pore-water profiles by sedimentary event and the significance of anaerobic oxidation of methane for the burial of sulfur in marine sediment. Geochim. Cosmochim. Acta, 67, 2631-2647.

Hoehler, T. M., M. J. Alperin, D. B. Albert, and C. S. Martens, 1994: Field and laboratory studies of methane oxidation in an anoxic marine sediment - evidence for a methanogensulfate reducer consortium. Global Biogeochem. Cycles., 8, 451-463.

Horng, C. S., and K. H. Chen, 2006: Complicated magnetic mineral assemblages in marine sediments offshore of southwestern Taiwan: possible influence of methane flux on the early diagenetic process. Terr. Atmos. Ocean. Sci., 17, 1009-1026.

Huang, C. Y., C. W. Chien, M. Zhao, H. C. Li, and Y. Iizuka, 2006: Geological study of active cold seeps in the syn-collision accretionary prism Kaoping slope off SW Taiwan. Terr. Atmos. Ocean. Sci., 17, 679-702.

Iversen, N., and B. B. Jorgensen, 1993: Diffusion coefficients of sulfate and methane in marine sediments: influence of porosity. Geochim. Cosmochim. Acta, 57, 571-578.

Jiang, W. T., J. C. Chen, B. J. Huang, C. J. Chen, Y. T. Lee, P. R. Huang, C. C. Lung, and S. W. Huang, 2006: Mineralogy and physical properties of cored sediments from the gas hydrate potential area of offshore southwestern Taiwan. Terr. Atmos. Ocean. Sci., 17, 981-1007.

Jorgensen, B. B., 1982: Mineralization of organic matter in the sea bed-the role of sulfate reduction. Nature, 296, 643-645.

Joye, S. B., A. Boetius, B. N. Orcutt, J. P. Montoya, H. N. Schulz, M. J. Erickson, and S. K. Lugo, 2004: The anaerobic oxidation of methane and sulfate reduction in sediments from Gulf of Mexico cold seeps. Chem. Geol., 205, 219-238. 
Kvenvolden, K. A., 1988: Methane hydrates and global climate. Global Biogeochem. Cycles, 2, 221-229.

Kvenvolden, K. A., 1993: Gas hydrates-Geological perspective and global change. Rev. Geophys., 31, 173-187.

Li, Y. H., and S. Gregory, 1974: Diffusion of ions in sea water and in deep-sea sediments. Geochim. Cosmochim. Acta, 38, 703-714.

Lin, S., and J. W. Morse, 1991: Sulfate reduction and iron sulfide mineral formation in Gulf of Mexico anoxic sediments. Am. J. Sci., 291, 55-89.

Lin, S., K. M. Huang, and S. K. Chen, 2002: Sulfate reduction and iron sulfide mineral formation in the southern East China Sea continental slope sediment. Deep-Sea Res., 49, $1837-1852$.

Liu, C. S., I. L. Huang, and L. S. Teng, 1997: Structure features off southwestern Taiwan. Mar. Geol., 137, 305-319.

Liu, C. S., K. C. Chen, and P. Schnürle, 2003: Distribution and characteristics of gas hydrates offshore southwestern Taiwan. EOS Tran., AGU, Fall Meeting.

Liu, C. S., P. Schnürle, H. L. Chang, Y. Wang, S. H. Chung, and T. H. Hsiuan, 2004a: Geophysical characteristics and geological settings of bottom simulating reflectors offshore southwestern Taiwan. International Workshop on Gas Hydrate Exploration and Exploitation, CGS, MIEA, ROC.

Liu, C. S., B. Deffontaines, C. Y. Lu, and S. Lallemand, 2004b: Deformation patterns of an accrectionary wedge in the transition zone from subduction to collision offshore southwestern Taiwan. Mar. Geophy. Res., 25, 123-137.

Liu, C. S., P. Schnürle, Y. Wang, S. H. Chung, S. C. Chen, and T. H. Hsiuan, 2006: Distribution and characters of gas hydrate offshore of southwestern Taiwan. Terr. Atmos. Ocean. Sci., 17, 615-644.

MacDonald, G. J., 1990: Role of methane clathrates in past and future climates. Climatic Change, 16, 247-281.

Milkov, A. V., G. E. Claypool, Y. J. Lee, G. R. Dickens, W. Xu, and W. S. Borowski, 2003: In situ methane concentrations at Hydrate Ridge Offshore Oregon: new constraints on the global gas hydrate inventory from an active margin. Geology, 31, 833-836.

Milkov, A. V., 2005: Molecular and stable isotope compositions of natural gas hydrates: a revised global dataset and basic interpretations in the context of geological settings. Org. Geochem., 36, 681-702.

Niewohner, C., C. Hensen, S. Kasten, M. Zabel, and H. D. Schulz, 1998: Deep sulfate reduction completely mediated by anaerobic methane oxidation in sediments of the upwelling area off Namibia. Geochim. Cosmochim. Acta, 62, 455-464.

O'Dell, J. W., J. D. Pfaff, M. E. Gales, and G. D. McKee, 1984: The determination of inorganic anions in water by ion chromatography. Method 300.0, US EPA 600/4.84.017, 5 pp.

Orcutt, B. N., A. Boetius, S. K. Lugo, I. R. MacDonald, V. A. Samarkin, and S. B. Joye, 2004: Life at the edge of methane ice: microbial cycling of carbon and sulfur in Gulf of Mexico gas hydrates. Chem. Geol., 205, 239-251.

Oung, J. N., C. Y. Lee, C. S. Lee, and C. L. Kuo, 2006: Geochemical study on hydrocarbon gases in seafloor sediments, southwestern offshore Taiwan - implications in the potential occurrence of gas hydrates. Terr. Atmos. Ocean. Sci., 17, 921-931. 
Reeburgh, W. S., 1980: Anaerobic methane oxidation: rate depth distributions in Skan Bay sediments. Earth Planet. Sci. Lett., 47, 345-352.

Sassen, R., S. L. Losh, L. Cathles III, H. H. Roberts, J. K. Whelan, A. V. Milkov, S. T. Sweet, and D. A. DeFreitas, 2001: Massive vein-filling gas hydrate: relation to ongoing gas migration from the deep subsurface of the Gulf of Mexico. Mar. Petrol. Geol., 18, 551-560.

Sassen, R., H. H. Roberts, C. Robert, A. V. Milkov, D. A. DeFreitas, B. Lanoil, and C. Zhang, 2004: Free hydrocarbon gas, gas hydrate, and authigenic minerals in chemosynthetic communities of the northern Gulf of Mexico continental slope: relation to microbial processes. Chem. Geol., 205, 195-217.

Suess, E., 1980: Particulate organic carbon flux in the oceans-surface productivity and oxygen utilization. Nature, 288, 260-263.

Suess, E., M. E. Torres, G. Bohrmann, R. W. Collier, J. Greinert, P. Linke, G. Rehder, A. Tréhu, K. Wallmann, G. Winckler, and E. Zuleger, 1999: Gas hydrate destabilization: Enhanced dewatering, benthic material turnover and large methane plumes at the Cascadia convergent margin. Earth Planet. Sci. Lett., 170, 1-15.

Shyu, C. T., Y. J. Chen, S. T. Chiang, and C. S. Liu, 2006: Heat flow measurements over bottom simulating reflectors, offshore southwestern Taiwan. Terr. Atmos. Ocean. Sci., 17, 845-869.

Westrich, J. T., and R. A. Berner, 1984: The role of sedimentary organic matter in bacterial sulfate reduction: the G model tested. Limnol. Oceanogr., 29, 236-249.

Yang, T. F., G. H. Yeh, C. C. Fu, C. C. Wang, T. F. Lan, H. F. Lee, C. H. Chen, V. Walia, and Q. C. Sung, 2004: Composition and exhalation flux of gases from mud volcanoes in Taiwan. Environ. Geol., 46, 1003-1011.

Yang, T. F., P. C. Chuang, S. Lin, J. C. Chen, Y. Wang, and S. H. Chung, 2006: Methane venting in gas hydrate potential area offshore of SW Taiwan: evidence of gas analysis of water column samples. Terr. Atmos. Ocean. Sci., 17, 933-950.

Lin, S., W. C. Hsieh, Y. C. Lim, T. F. Yang, C. S. Liu, and Y. Wang, 2006: Methane migration and its influence on sulfate reduction in the Good Weather Ridge region, South China Sea continental margin sediments. Terr. Atmos. Ocean. Sci., 17, 883-902. 